\title{
KIRJOITUS
}

TITI GÄVERT

\section{Koronaerityinen diakoniatyö vastasi ketterästi akuuttiin tarpeeseen}

4 lokuussa 2020 opetus- ja kulttuuriministeriö myönsi Suomen evankeClis-luterilaiselle kirkolle ja Suomen ortodoksiselle kirkolle 4,5 M€ suuruisen erityisavustuksen, josta Suomen evankelis-luterilaisen kirkon osuus oli 4,43 M€. Erityisavustus jaettiin seurakunnille alueen kunnan tai kuntien väkiluvun suhteessa. Avustuksen tavoite oli tukea seurakuntien diakoniatyötä ja ylläpitää seurakuntien kykyä osallistua ihmisten auttamiseen yhteiskunnan toipuessa koronapandemiakriisistä. Kukin seurakunta suunnitteli ja toteutti itsenäisesti oman koronaerityisen toimintansa. Tämä kirjoituksen pohjana on opetus- ja kulttuuriministeriölle luovutettu raportti Suomen evankelisluterilaisessa kirkossa erityisavustuksella tehdystä työstä.

\section{Koronapandemia muutti diakoniatyötä}

Diakoniatyöntekijät muuttivat ketterästi työotettaan vastaamaan koronapandemian aiheuttamaan ajankohtaiseen tilanteeseen. Avun antamisen keinot muokkautuivat ja kehittyivät koronatilanteen mukaisesti useampaan kertaan. Keväällä 2020 ryhmätoiminnot jäivät tauolle, retket ja leirit peruttiin. Erityisesti ruoka-avustaminen ja muu taloudellinen avustaminen organisoitiin uudelleen. Syksyn 2020 ja kevään 2021 aikana joitakin aiempia toimintatapoja voitiin ottaa takaisin käyttöön, mutta suunnitelmien osalta oli elettävä jatkuvasti epävarmuudessa toteutushetkeen saakka. Vaikka monet toiminnot suljettiin kokonaan, diakonia ei mennyt missään vaiheessa kiinni, vaan diakoniatyöntekijät vahvistivat sidosryhmäyhteistyötä ja etsivät uusia toimintata- 
poja heikoimmassa asemassa olevien tavoittamiseksi.

Muutokset ihmisten arjessa näkyivät diakoniatyössä heti. Koronapandemian alkumetreiltä alkaen diakoniatyöntekijät raportoivat ihmisten kokemasta avuntarpeesta: ahdistus epävarmuudesta, pelko, yksinäisyys, mielenterveysongelmat, perheiden haasteet, itsemurhat, vanhusten ja nuorten vaikea tilanne. Samat ilmiöt nousivat myöhemmin esiin myös valtakunnallisessa mediassa.

Koronavuosien diakoniatyön muutos näkyy kirkon tilastoissa. Diakoniatyö painottui yksilökohtaamisiin, joita oli ensimmäisenä koronavuonna 2020 jopa 34 \% edellisvuotta enemmän. Kohtaamisten määrät kasvoivat merkittävästi kaikissa ikäryhmissä ja perherakenteissa nuorista aikuisista alkaen, mutta määrällisesti eniten apua hakivat yksin asuvat työikäiset ihmiset.

Opetus- ja kulttuuriministeriön erityisavustuksesta 55 \% kanavoitiin diakoniatyön kautta suorina avustuksina yksityisille ihmisille. Suurin osa työstä tehtiin olemassa olevalla henkilöstöllä, minkä lisäksi koronaerityiseen työhön palkattiin myös lisätyövoimaa. Henkilöstöresursseihin käytettiin 27 \%. Korona-ajan toimintojen kuluihin käytettiin $12 \%$ ja koronaerityisen työn laite- ja kalustohankintoihin $6 \%$.

\section{Ruoka-avustaminen palasi yhteisöruokailuista ruokakasseihin}

Ruoka-avustaminen muuttui radikaalisti pandemian aikana. Vuoteen 2019 mennessä ruoka-avustamisen painopiste oli paljolti siirretty hävikkilahjoituselintarvikkeiden jakamisesta monitoimijaisesti toteutettuihin yhteisöruokailuihin, joiden tavoitteena oli vahvistaa kävijöiden osallisuuden kokemusta, tarjota edullista ruokaa ja mielekästä tekemistä. (Mäntylä, Nousiainen \& Isola, 2019.) Ennen koronapandemiaa yhteisöruokailuissa kävi lähes 370000 ruokailijaa.

Koronapandemian myötä yhteisöruokailut oli laitettava tauolle. Samaan aikaan ruoka-avun tarve kasvoi lomautusten, etäkoulujen ja muiden taloudellisten muutosten myötä. Ruoka-apu piti nopeasti organisoida uudelleen. Aiempia hävikkiruuan jakamisen muotojakaan ei voinut käyttää, sillä jonottamiseen ja omaan valintaan perustuvat jakotilaisuudet eivät olleet turvallisia. Sen sijaan jaettiin valmiiksi pakattuja ruokakasseja, joissa yhdistettiin EU-ruokaa, hävikkiruokaa, erityisavustuksella hankittuja elintarvikkeita sekä hygieniatuotteita (kuten maskeja). 
Jaettujen ruokakassien määrä kaksinkertaistui vuodesta 2019 vuoteen 2020, ja kasvu on jatkunut huikeana keväällä 2021. Ruoka-avun saajina oli ikääntyneitä, lapsiperheitä, opiskelijoita, lomautettuja, eri syistä työelämän ulkopuolella olevia sekä köyhyyttä kokevia. Ruoka-apua tarvittiin esimerkiksi perheissä etäopetuksen aikana keväällä 2020 ennen kuin kunnat aloittivat ruoan jakelun peruskoululaisille. Yksin asuville toisen asteen opiskelijoille apua on tarvittu pitempään. Ruoka-apu oli nopea hätäratkaisu syntyneeseen turvaverkkojen katveeseen, jossa yhteiskunnan tuki pystyi vasta viiveellä reagoimaan ihmisten koronapandemian aiheuttamiin tulomuutoksiin (Salonen, 2020).

Kasvokkaisten kohtaamisten merkitys korostui korona-aikana. Koronatilanteen niin salliessa diakoniatyössä järjestettiin mahdollisuuksia tavata kahvin tai keiton äärellä koronaturvallisesti ulkona. Seurakuntien työntekijät kuuntelivat kuulumisia ja tarjosivat kahvia ja keittoa toreilla ja kirkon pihoilla. Ruoka-avun lisäksi yhteisöllisillä ulkolounailla mahdollistettiin turvallisia kohtaamisia katkaisemaan eristäytynyttä yksinoloa.

Sosiaalibarometrissa (Eronen ym., 2021) diakoniatyön myöntämän ruoka-avun, taloudellisen avun ja keskusteluavun merkitys osana aikuissosiaalityötä korostui erityisesti pienemmissä ja keskisuurissa kunnissa. Sosiaalitoimi teki vuonna 2020 yhteistyötä seurakuntien kanssa varsinkin ruoka-avustamisessa ja ikääntyneiden tavoittamisessa. Alle 75000 asukkaan paikkakuntien aikuissosiaalityön vastaajista puolet kertoi lisänneensä yhteistyötä seurakuntien kanssa korona-aikana. (emt.)

\section{Taloudellinen avustaminen toimi täsmäapuna erilaisiin tilanteisiin}

Suomen evankelis-luterilaisen kirkon seurakunnat käyttävät vuositasolla n. 6,6M€ diakoniatyön taloudellisiin avustuksiin. Vuonna 2020 avustusten summa oli n. 8,4 M€t, mikä on $27 \%$ enemmän kuin edeltävänä vuonna. Koronaerityisestä avustusmahdollisuudesta tiedottaminen toi diakoniatyön avun piiriin aiempaa enemmän yrittäjiä, maataloustuottajia sekä eri alojen lomautettuja työntekijöitä.

Diakoniatyössä myönnettiin osto-osoituksia tai lahjakortteja päivittäistavaraliikkeeseen, josta avun saaja voi ostaa itse valitsemiaan elintarvikkeita ja hygieniatuotteita. Koronaerityisenä avustuksena myönnettiin lisäksi henkistä 
hyvinvointia lisääviä lahjakortteja paikallisten pienyritysten palveluihin, kuten kampaajalle, hierontaan tai urheilukeskukseen. Taloudellisilla avustuksilla oli apua saaneiden tilanteen helpottamisen lisäksi välillinen myönteinen vaikutus paikkakuntien yrittäjiin.

Avustuksena on myös maksettu asumiseen tai elämiseen liittyviä laskuja tilanteissa, joissa asiakas ei ole oikeutettu toimeentulotukeen, tai toimeentulotuesta huolimatta taloustilanne on äärimmäisen niukka. Avustussumman ohella keskusteluapu ja henkinen tuki sekä mahdollinen talous- ja palveluneuvonta voivat olla jopa rahallista apua merkityksellisempiä avun muotoja (Juntunen, 2006).

\section{Ikääntyneiden tavoittaminen erityistehtävänä}

Diakoniatyössä keskeiseksi toiminnaksi heti pandemian alussa nousi iäkkäiden ja muiden eristyksissä pysyttelevien erityisryhmien yksinäisyyden torjunta sekä arjen sujumisen ja hyvinvoinnin varmistaminen asiointiavulla. Yhdessä muiden toimijoiden kanssa organisoitiin ikääntyneiden kattava kontaktointi. Esimerkiksi Helsingissä ja Vantaalla seurakunnat organisoivat toimintamallin, jossa puhelimitse pyrittiin tavoittamaan kaikki yli 70-vuotiaat kuntalaiset. Puheluissa kysyttiin kuulumisia, tarkistettiin avun tarve ja organisoitiin tarvittaessa asiointiapua (mm. lääkekuljetukset apteekista), ruoka-apua ja muuta tarvittavaa apua kotiin tai kotiovelle. Hanke toteutettiin yhteistyössä seurakunnan, kunnan ja muutamien järjestöjen kanssa. Konkreettisen avun lisäksi monissa seurakunnissa haluttiin huomioida ylipäätään kaikkia yli 70-vuotiaita karanteenin vuoksi pitkän aikaa kotona olevia kotiin lähetettävällä tai vietävällä tervehdyksellä.

\section{Moniulotteinen digiloikka}

Ennen korona-aikaa diakoniatyöntekijät kohtasivat lähes viikoittain henkilöitä, jotka eivät osanneet tai voineet käyttää digipalveluja (Alava ym., 2020). Pandemia-aikana tästä tuli erityinen haaste, kun lähikohtaamisten tilalle oli tarjolla vain etäpalveluja ja etäkohtaamisia. Niille, jotka olivat tottuneet käyttämään digipalveluissa asiointiin esimerkiksi kirjastojen tietokoneita ja verkkoyhteyksiä, ei ollut tarjolla korvaavia mahdollisuuksia, kun kirjastoja pandemian vuoksi suljettiin. Seurakunnat edistivät digiympäristöön pääsyä 
järjestämällä digilaitteita. Esimerkiksi hoivakotien asukkaille hankittiin yhteiskäyttöisiä tabletteja ja vähävaraisille toisen asteen opiskelijoille kannettavia tietokoneita (läppäreitä).

Seurakunnat tuottivat aiempaa enemmän tukea ja apua verkkoympäristössä. Kohtaamisia pyrittiin kompensoimaan digitaalisin yhteydenpitokeinoin. Vertaistukiryhmiä ja matalan kynnyksen kohtaamispaikkoja siirrettiin verkkoon. Korjattiin digitaitojen puutteita ja mahdollistettiin asiointia ja osallistumista yhteiskuntaan useimpien läsnä olevien palvelujen sulkeuduttua. Tällä työllä on todennäköisesti kauaskantoisia vaikutuksia, sillä pandemian helpotuttuakin merkittävä osa yhteiskunnallisesta toiminnasta tapahtuu verkkoympäristössä.

\section{Yli työalarajojen ja tiivistyvään yhteistyöhön}

Suomen evankelis-luterilaisessa kirkossa on noin 1300 diakoniatyöntekijää (Alava ym., 2020). Useimmissa seurakunnissa koronaerityiseen auttamistyöhön tuli diakoniatyöntekijöiden rinnalle myös muiden työalojen työntekijöitä, kuten lapsityöntekijöitä, pappeja, nuorisotyöntekijöitä ja keittiöhenkilökuntaa. Työalarajojen yli päästiin ja työntekijäresursseja käytettiin luovasti ja ketterästi. Olemassa olevan henkilöstön lisäksi koronaerityiseen toimintaan palkattiin erityisavustuksen turvin 25 kokoaikaista ja 54 osa-aikaista työntekijää: diakoniatyöntekijöitä, diakonia-avustajia, perhetyöntekijöitä, ruokapalvelun henkilöstöä. Palkatut lisäresurssit olivat määräaikaisia ja toimivat vakituisen henkilöstön apuna kriittisimpien kuukausien ajan.

Diakoniatyöntekijöiden normaalioloissa muodostamat yhteistyöverkostot ja yhdessä tekemisen muodot muun muassa kunnan sosiaalitoimen, hoivapalveluyksiköiden ja paikallisten järjestöjen kanssa sekä olemassa olevat kontaktit suoraan heikoimmassa asemassa oleviin mahdollistivat tehokkaan toiminnan kriisiaikana. Sote-johtajat kuvasivat seurakuntien roolin keskeisenä erityisesti ruoka-avussa, asiointiavussa, maskien jakamisessa vähävaraisille, ikääntyneiden tavoittamisessa ja psykososiaalisessa tuessa. Yhteisen tilannekuvan muodostaminen kunnallisissa valmiusryhmissä auttoi muokkaamaan työtä ja uudelleensuuntaamaan resursseja tehokkaasti. (Eronen ym., 2021:75-77.) 


\section{Arviointia ja johtopäätöksiä}

Erityisavustuksella tehdyn työn tavoitteena oli ihmisten auttaminen pandemian aikana. Seurakunnat saivat päättää itsenäisesti rahan käytöstä. Tämä vaikuttaa olleen viisas linjaus. Toimintatapoja muokkaus ja uusien kehittäminen vastasi paikallisiin ajankohtaisiin avuntarpeisiin.

Pääsääntöisesti keinot olivat valtakunnallisesti samat - kohtaaminen, keskusteluapu sekä maltillinen taloudellinen apu joko konkreettisena ruokana tai asiointiapuna tai lahjakorttina joko päivittäistavaraliikkeeseen tai hyvinvointia edistävään palveluun. Allardtin (1993) mallin laajennetun hyvinvoinnin (mm. Hiilamo, 2021) ulottuvuuksissa tarkasteltuna diakonian pääpaino oli resurssien minimin turvaamisessa ruoka-avun ja avustusten myötä (having) sekä yhteyksien luomisessa ja kohtaamisessa (loving). Muut osa-alueet (doing, being) laitettiin odottamaan koronapandemian helpottamista. Yhteyksien mahdollistajana diakonia toimi toisin kuin valtaosa muusta palvelujärjestelmästä (vrt. Hiilamo, 2021).

Korona-aikana on tavoitettu myös niitä, jotka eivät ole olleet aiemmin seurakunnan diakoniatyön avun ja toiminnan piirissä. OKM erityisavustus kannusti tekemään uusia avauksia, sillä sen myötä oli jonkin verran ylimääräistä varaa kustannusten kattamiseen. Erityisavustuksen rohkaiseva ja innostava merkitys on ollut jopa rahallista arvoa suurempi.

Koronapandemian oheishyötynä tuli valtava digiloikka, jossa pakkotilanteessa on opeteltu sekä tuottamaan että käyttämään digitaalisen ympäristön mahdollisuuksia asiointiin ja kohtaamiseen. On tärkeää varmistaa myös jatkossa kaikkien mahdollisuus olla osa myös digiympäristössä toimivaa yhteiskuntaa. Erityisenä haasteena korona-aika toi näkyväksi ongelmat, jotka liittyvät toisen puolesta asiointiin joko sairauden tai kuoleman kohdatessa.

Koronapandemia korosti yhteistyön merkitystä (mm. Salonen \& Alppivuori, 2021). Pandemian aikana syventyneitä ja rakentuneita kumppanuuksia sekä hyväksi havaittuja käytäntöjä on hyvä jatkaa ja kehittää edelleen kunnan, seurakunnan ja järjestöjen yhteisenä hyvinvoinnin ja terveyden edistämisenä.

\section{Kirjallisuus}

Alava, H., Kela, A., Nikkanen, A., \& Paloviita, P. (2020). Aina uuden edessä. Diakoniabarometri 2020. Suomen ev.lut. kirkon julkai- suja 88. Helsinki: Kirkkohallitus.

Allardt, E. (1993). Having, loving, being. An alternative to the Swedish model of wel- 
fare research. - Nussbaum, M., \& Sen, A. (toim.) The Quality of Life. Oxford: Clarendon Press, 88-94.

Diakonisen toiminnan periaatteet ja suuntaviivat. https://evl.fi/plus/seurakuntaela$\mathrm{ma} /$ diakonia/tietoa-diakoniasta/diakonisen-toiminnan-periaatteet

Eronen, A, Hiilamo, H, Ilmarinen, K. ym. (2021). Koronakriisi ja palvelujärjestelmän joustavuus. Sosiaalibarometri 2021. Helsinki: Soste.

Gävert, T., \& Saarela, T. (2021). Koronavuosien diakonia. Hankeraportti OKM erityisavustuksen käytöstä Suomen evankelis-luterilaisen kirkon diakoniatyössä 2020-2021. Kirkkohallitus.

Hiilamo, H. (2021). Koronakriisin sosiaalinen velka. Miten koronapandemia vaikuttaa laaja-alaiseen hyvinvointiin? Helsinki: Kalevi Sorsa -säätiö.

Juntunen, E. (2006). Viimeisellä luukulla. Tutkimus viimesijaisen sosiaaliturvan aukoista ja diakoniatyön kohdentumisesta. Helsinki: Kirkkohallitus.

Kuusimäki, K. (2020). Pääkirjoitus: Korona- keväästä koronasyksyyn. Diakoniaplus. fi. https://www.diakoniaplus.fi/koronakevaasta-koronasyksyyn/ - Viitattu 1.11.2021.

Mäntylä, E., Nousiainen, M. \& Isola, A.-M. (2019). Keittiöt ilman rajoja. Yhteinen keittiö-hankkeen osallisuusvaikutusten arviointi. Helsinki: Terveyden ja hyvinvoinnin laitos.

Salminen, V-M. (2021). Seurakuntatyö pitkittyneessä poikkeustilassa. Tampere: Kirkon tutkimuskeskus.

Salomäki, H. (2020). Seurakunnat ja koronakriisi. Tampere: Kirkon tutkimuskeskus.

Salonen, A-S. (2020). Ruoka-apu, mielikuvitus ja tulevaisuus. Diakonian tutkimus 2, 27-33.

Salonen, A-S., \& Alppivuori, K. (2021). Kaupungin ja järjestökentän yhteistyö espoolaisen ruoka-avun kentällä koronakriisissä keväällä 2020. Diakonian tutkimus 1, 6-31. Suomen evankelis-luterilainen kirkko (2021). Toimintatilasto 2021. https://www.kirkontilastot.fi - Viitattu 1.10.2021. 